\title{
Plasma Cholesteryl Ester Transfer Protein (CETP) in Relation to Human Pathophysiology
}

\author{
Akihiro INAZU, MD \\ Department of Laboratory Sciences \\ School of Health Sciences \\ Institute of Medical, Pharmaceutical and Health Sciences \\ Kanazawa University
}

\section{Address}

Kodatsuno 5-11-80

Kanazawa, 920-0924, Ishikawa, JAPAN

E-mail

inazua@mhs.mp.kanazawa-u.ac.jp

\section{Key words}

CER, cholesterol esterification rate

CETP, cholesteryl ester transfer protein

CHD, coronary heart disease

FC, free cholesterol

LCAT, lecithin: cholesterol acyltransferase

RCT, reverse cholesterol transport

Running title; CETP and Atherosclerosis 
ABSTRACT Plasma cholesteryl ester transfer protein (CETP) facilitates neutral lipid exchange among lipoproteins. As in the case of naturally CETP -deficient animals such as mice, rat and dogs, the deficiency of CETP in human results in increased HDL levels due to decreased catabolism of HDL apoA-I and decreased LDL levels due to increased catabolism of LDL apoB. Also, post-prandial lipemia is diminished, and remnant cholesterol levels are also decreased. Genetic polymorphisms of the CETP gene promoter slightly decrease plasma CETP activity (-20\%) and accordingly increase HDL-C concentration,. Meta-analysis of clinical data has suggested that these changes result in decreased thereby decreasing coronary risk in meta-analyses. The Llipoprotein phenotype found in CETP-deficient heterozygotes, who had decreased plasma CETP activity by $-40 \sim 50 \%$, appeared to be anti-atherogenic in most studies. However, the effect on atherogenicity remains to be established in a large population study of subjects with very high HDL (>100 mg/dl) by due to homozygous CETP deficiency. The result is not predictable, because large, apoE-rich HDL would might on the one hand operate as a platform of apoCs and apoE and lipoprotein-associated enzymes but on the other hand it is be less active cholesterol acceptors for ABCA1 transporters. 


\section{Introduction (Figure 1)}

Plasma LDL transports cholesterol from liver to peripheral tissues including adrenal glands and gonads. On the other hand, HDL transports cholesterol from peripheral tissues including atheroma to liver, subsequently to bile and feces via so-called reverse cholesterol transport (RCT) pathway. Cholesterol structure is resistant to enzymatic degradation in a humans body,. only thethe only pathway to modify cholesterol is its hydroxylation for excretion from the body.

In human, HDL is consistsed of heterogenous particles heterogeneous in size, density and apolipoprotein composition. HDL is a vehicles for cholesterol, triglyceride, and phospholipids. Also, HDL has several apolipoproteins and enzymes on its surface that either promoteing or inhibiting triglyceride or phospholipids lipolysis, inhibiting hydroperoxidation of lipids, and promoteing lipid transfer among lipoproteins. In addition, HDL may be a platform for complement regulation, coagulation and inflammation [Scanu and Edelstein, 2008].

Plasma HDL content islevels are usually measured as cholesterol levels concentration, but its particle numbers are better assessed by apolipoprotein A-I levels. 
This distinction may be due in part to the fact that As inter-individual differences of plasma HDL-cholesterol, HDL2-cholesteol levels appeared to be highly variable, but HDL3 remains constant. Smoking, and male sex decreases HDL2 levels, but alcohol intake and exercise increase them. HDL2 levels were determined by result from catabolismc rate of apolipoprotein A-I and A-II rather than altered synthesistic rate. The catabolic rate of HDL apolipoproteins is determined by HDL particle size. The smaller HDL tends to be faster catabolized in the kidney or other tissues. One of the determinants of HDL neutral lipid composition is plasma cholesteryl ester transfer protein (CETP).

In incubated human plasma, transfer and equilibration of lecithin: cholesterol acyltransferase (LCAT)-generated CE is found, but the activity transferring CE among lipoproteins was not found in rat [Barter and Lally, 1978]. Similarly, mice, dog, and pig were members of a group of low plasma CETP activity, but rabbit and monkey belong to a group of high CETP activity. Human, hamster, guinea pig and chicken belong to a group of with intermediate CETP activity. Interestingly, more phospholipid transfer protein activity is found in plasmas of low CETP activity animals [Ha and 


\section{Barter 1982; Cheung et al. 1996].}

Plasma CETP binds neutral lipids (CE or TG) and PL on HDL3, but CETP selectively promotes an exchange of CE and TG among lipoproteins. SinceOn the one hand HDL-TG couldcan be hydrolyzed by hepatic lipase, and on the other hand plasma CETP decreases HDL particle size via CE/TG exchange between chylomicron / VLDL and HDL. Thus CETP, thereby accelerates thing a catabolic rate of HDL apolipoproteins

\section{[Lamarche et al. 1999].}

\section{Structure of CETP}

Plasma CETP was initially isolated as a highly purified 74kD protein [Pattnaik et al.

1978]. The human CETP gene is located at chromosome 16q13, near the locus of LCAT gene. The CETP gene consists of 16 exons, spanning 25kb [Agellon et al. 1991]. The CETP mRNA encodes 476 amino acids [Drayna et al. 1987]. The mature CETP contains four N-linked sugars (88, 240, 341, and 396) with variable glycosylation site of 341Asn [Stevenson et al. 1993]. CETP mRNA is expressed in various tissues, but liver cells, adipocytes and macrophages are abundant sources. Exon 9 works a cassette exon to generate short mRNA missing the sequences in frame in addition to full-length 
mRNA, but the splice-out variant is not efficiently secreted [Inazu et al. 1992].

The C-terminal 26 amino acids of CETP form an amphipathic helix. Hydrophic residues bind to surface lipoproteins, and hydrophobic residues such as Leu, Phe are essential for binding neutral lipids such as CE and TG [Wang et al. 1993].

The crystal structure of CETP shows that CETP forms a long tunnel occupied by four lipid molecules, two of CE or TG located inside of the tunnel and two of PL plugging both sides of the tunnel openings. CETP is one of the lipopolysaccharide binding protein (LBP) family members. CETP exhibits an elongated boomerang shape located on the lipoprotein surface. Based on molecular size, CETP might prefer CE transfer rather than TG because of steric hindrance to TGs at the tunnel neck around residues of 433, 443, 457, and 459 [Qiu et al. 2007].

\section{Regulation of CETP expression}

Cholesterol-rich and saturated fat-rich diet increased CETP expression via a liver X receptor (LXR) element in the promoter, a direct repeat of a nuclear receptor binding sequence separated by 4 nucleotides (DR4) [Luo and Tall. 2001].

Among drugs that lower lipid levels, probucol increased plasma CETP activity 
(+20\%), but pravastatin decreased it (-20\%) [Inazu et al. 1999]. Statins decrease both cholesterol and oxysterosl, the latter being a ligand for LXR $\alpha$ activity [Masson et al. 2004]. Thus, statins could decrease CETP mRNA levels through diminished LXR activity. However, the molecular effect of probucol on CETP expression is unknown, but it may be associated with increased cholesterol content in the liver by the remnant pathway. Unlike bezafibrate, fenofibrate decreased plasma CETP activity (-20 30\%) [Guerin et al. 1996; Watts et al. 2006]. Since a putative PPRE is located in the just upstream of the LXR $\alpha$ site, PPAR $\alpha$ could suppress CETP promoter activity by antagonizing LXR activity [Cheema et al. 2005].

Nicotinic acid is a well-established lipid-lowering agent. Side effects such as flushing may restrict drug usage, however, recent identification of a $G$ protein-coupled receptor GPR109A and of a PGD2 receptor antagonist (laropiprant) may provide strategies to control side effects. Nicotinic acid is a powerful inhibitor of fat-mobilizing lipolysis via hormone-sensitive lipase in adipose tissue, and therefore limits FFA flux into the liver. Nicotinic acid lowers TG as well as Lp(a) levels, and increases HDL-C levels by $\sim 20-40 \%$. Nicotinic acid may induce PPAR $\gamma$ expression but it is also 
reported to lower CETP activity. Nicotinic acid increased HDL cholesterol levels by reducing hepatic CETP mRNA only in mice expressing the human CETP transgene

[Hernandez et al. 2007; Van der Hoorn et al. 2008].

\section{Function of CETP}

LCAT promotes FC esterification in HDL3 and CETP transfers newly-esterified CE from HDL3 to VLDL or chylomicrons. Thus, these tandem reactions appeared to be physiological. However, it has been unclear whether or not CETP is pro-atherogenic, but it is likely that its atherogenicity is dependent on the metabolic context of lipoprotein receptors expressed in the liver, which are major determinants of RCT pathways to the liver.

4.1 LCAT, cholesterol esterification, and CE transfer rate (Table 1)

Table 1 shows simultaneously determined plasma exogenous LCAT activity and CER and exogenous CETP activity in young women. Plasma cholesterol esterification rate (CER) is an endogenous LCAT reaction, which shows only 20\% of maximal enzymatic activity of LCAT. Net CE transfer rate from HDL to VLDL is only 20 50 $\mathrm{nmol} / \mathrm{ml} / \mathrm{h}$ despite exogenous CETP activity $\sim 200 \mathrm{nmol} / \mathrm{ml} / \mathrm{h}$ [Pruneta et al. 1999]. 
Since net CE transfer rate is smaller than that of CER, CE in HDL needs to be directly catabolized in liver. Therefore plasma VLDL levels appear to be a rate-limiting step of net CE transfer rate in the fasting state. However, in the post-prandial state, net CE transfer is accelerated because the increased VLDL / chylomicrons provides increased CE acceptor capacity, and the clearance of LDL-CE or remnant-CE is dependent on LDL-receptor activity or remnant receptor (LRP) in the liver. Since HDL-FC is more rapidly catabolized in liver than HDL-CE in a monkey study, selective uptake of FC without endocytosis of HDL apolipoproteins appears to be a predominant pathway of HDL-C catabolism in the liver [Scobey et al. 1989]. Thus HDL-CE pathways play minor roles in human HDL-cholesterol catabolism [Schwartz et al. 2004]. Also, FC from HDL is efficiently secreted in bile, but not from other lipoproteins [Robins and Fasulo, 1997]. Thus, cholesterol esterification is not necessarily required for the selective uptake of HDL-cholesterol in the liver via hepatic lipase and SR-BI mediated RCT pathways. The lipoprotein phenotype of high HDL and the low CER appear to be anti-atherogenic because efficient RCT is maintained in the liver.

\subsection{Modulators of lipid transfer}


CETP-mediated lipid transfer is not preferably directed toward a specific lipoprotein in a reconstituted system. Because CE is generated in HDL via the LCAT reaction, higher CE concentrations are found in HDL Therefore, net CE transfer operates from HDL to other lipoproteins in vivo. Similarly, because chylomicrons and VLDL are rich in TG, net TG transfer is found from chylomicron / VLDL to other lipoproteins via hetero-exchange of CE and TG. In addition, some specific apolipoproteins and TG lipolysis occurring during the post-prandial state would modify the direction of lipid transfer among lipoproteins.

As a modulator of CE transfer, apoF was identified as lipid transfer inhibitor protein (LTIP). LTIP inhibits CE transfer between VLDL and LDL, whereas it increases CE transfer from HDL to VLDL [Wang and Morton 1999]. PLTP promotes PL transfer from VLDL to HDL, in addition to the PL transfer activity of CETP. Also, PLTP possesses free cholesterol and vitamin E transfer activity. As CE acceptors of CE transfer reaction, VLDL and chylomicrons are active when lipolysis has occurred. VLDL-bound LPL and FFA levels may have a positive effect on the binding between CETP and lipoproteins, thereby accelerating CE mass transfer. 


\subsection{Effects of CETP on LDL subclass remodeling}

An association of large LDL and low CETP activity with Taq1B polymorphism was found in men, but not in women in the genetic epidemiological survey of Framingham Study [Ordovas et al. 2000]. In remodeling of apoB-containing lipoproteins, addition of CE increases lipoprotein size and deletion of PL and FC decrease its size, resulting in 2 homogenous LDL subclasses [Musliner et al. 1991]. Complete CETP deficiency produced unique characteristics of broad LDL band with (at least 5) distinct IDL-LDL subclasses on a native polyacrylamide gel [Sakai et al. 1991], but partial CETP deficiency increased LDL size.

\subsection{Effects of CETP on macrophage-specific RCT in mice and hamsters}

In radioactive cholesterol-labeled macrophage methodology, Rader et al have shown direct RCT from peripheral macrophages to liver, bile and feces. In LDLR-KO mice, CETP cDNA adeno-associated virus mediated transfection promotes cholesterol transport to the liver, but not to bile and feces. In contrast, in SRBI-KO mice, CETP cDNA transfection increased cholesterol loss in the feces, indicating induction of overall RCT via active LDL-R activity despite diminished selective uptake of HDL-CE (or FC) 
in the liver [Tanigawa et al. 2007]. The former model is similar to the setting of familial hypercholesterolemia (FH) or down-regulated LDL receptor activity by a saturated-fat diet, while the latter model of decreased SR-BI activity reflects conditions found in the hormone replacement therapy [Oliveira et al. 2003]. Thus, macrophage-specific RCT is dependent on CETP activity and LDL receptor in the liver, and the efficacy of fecal sterol excretion is not always correlated with atherogenicity of plasma lipoproteins, indicating that measuring fecal sterol is not useful as a CHD biomarker.

In hamsters, torcetrapib, a CETP inhibitor, elevated HDL-C levels and the amounts of cholesterol and bile acids secreted in feces, indicating an overall increased RCT [Tchoua et al. 2008]. Such a difference may be explained (at least in part) by the presence of natural CETP activity and the inducible CYP7A gene found in hamsters

\section{[Zhang AH et al. 2004].}

4.5 Effects on cholesterol efflux and pre $\beta$ HDL formation

Subjects with complete CETP deficiency have more pre $\beta$ HDL despite less remodeling from large HDL to small subclasses via CETP [Asztalos et al. 2004]. Thus, 
increased pre $\beta$ HDL levels are caused by impaired maturation to large HDL due to decreased endogenous LCAT activity [Oliveira et al. 1997] or increased lipolysis of TG-rich lipoproteins [Miyazaki et al. 2009]. Since LCAT mass and exogenous LCAT activity remain at normal levels, impaired LCAT activity is explained either by 1) end-product inhibition namely excess CE in large HDL or by 2) altered phospholipid composition, such as sphingomyelin (SM) levels, in HDL. Plasma cholesterol esterification rate was decreased in CETP deficiency, which is compatible with altered lipid composition found in homozygous CETP deficiency; i.e. high CE/TG ratio and low PL/FC ratio [Koizumi et al. 1991]. Since CER is inversely associated with SM/PC ratio in HDL, SM itself may be an unsuspected link between low cholesterol esterification rate and low CETP activity [Noguchi and Inazu, unpublished data]. However, SM-rich lipoproteins are not always pro-atherogenic, because SM avidly binds cholesterol, and HDL with increased SM levels may be good acceptors for cholesterol efflux from atherosclerotic plaques [Fournier et al. 1997]. Increased HDL levels found in CETP deficiency had no beneficial effect on the ABCA1-mediated cholesterol efflux but did enhance SR-BI-mediated efflux [Miwa et al. 2009]. 
4.6 Lipoprotein metabolism in CETP deficiency from a kinetic study

Initially, Ikewaki et al reported delayed catabolism of apoA-I and apoA-II in human subjects with CETP deficiency [Ikewaki et al. 1993]. Also, they reported increased catabolic rate of LDL-apoB in addition to decreased production rate of VLDL-apoB [Ikewaki et al. 1995]. In a CETP-deficient dog, Ouguerram et al reported that VLDL and LDL CE metabolism was coupled to apoB catabolism without enrichment of CE during VLDL-LDL conversion and that $60 \%$ of HDL CE turnover was mediated by a selective uptake pathway [Bailhache et al. 2004; Ouguerram et al. 2004]. As compared to other CETP-deficient animals, dogs have higher selective uptake of HDL-CE (60\% vs. 25-30\% in rat and mice). The cholesterol esterification rate of dog plasma is $160 \mathrm{nmol} / \mathrm{ml} / \mathrm{h}$, which is between the rates in human $(30-80 \mathrm{nmol} / \mathrm{ml} / \mathrm{h})$ and in rats (300 nmol/ml/h). Thus, dogs may have an efficient RCT due to high activities of SR-BI and LCAT in addition to CETP deficiency.

\section{Role of CETP in apoE-rich HDL formation}

5.1 structure of apoE-rich HDL 
Plasma HDL is classifief as HDL1 (density 1.08-1.09 g/ml), HDL2 (1.09-1.15), and HDL3 (1.15-1.18). HDL1 is apoE-rich with a diameter of 13-19nm And increased LCAT activity compared with HDL2 and HDL3 [Schmitz and Assmann, 1982]. HDL1 is also identified in cholesterol-fed CETP-deficient animals such as canine and swine.

5.2 Function of apoE-rich HDL

In cultured smooth muscle cells, cholesterol from HDLc, lipoproteins with apoE only (density 1.006-1.02), present in cholesterol-fed canine plasma, was efficiently delivered to the cells as well as LDL [Mahley et al. 1977]. ApoE-rich HDL appears in various situations such as genetic dyslipidemia, but its characteristics may not be uniform. In cholesterol-fed canine, plasma cholesterol increases, HDL loses apoA-I but it gains apoE. HDLc appears (as well as occurrence of LDL and $\beta$-migrating VLDL) when cholesterol exceeds $700 \mathrm{mg} / \mathrm{dl}$. Thus, HDL1 and HDLc appeared to suppress apoB-containing lipoprotein formation in the liver, such as LDL and $\beta$-VLDL. Thus, one would predict that these lipoproteins would inhibit atherogenesis in canine models.

ApoE-rich HDL have dual roles in atherogenicity. ApoE can serve as an LRP ligand, and therefore canine HDLc inhibits clearance of chylomicrons [Hussain et al. 1995]. 
However, post-prandial lipemia is diminished in homo- and heterozygous CETP

deficiency [Inazu et al. 2008]. VLDL lipolysis and hepatic uptake of CM/VLDL

remnant appear to be increased probably due to apoE transfer from HDL to CM/VLDL

during post-prandial periods [Krimbou et al. 2003].

ApoE-rich HDL reduces LPL-mediated retention of LDL by subendothelial matrix, and therefore could be anti-atherogenic role in artery walls. Also, apoE-rich lipoproteins protect cells from apoptosis via the LRP signaling pathway [Hayashi et al. 2007].

In SB-B1 knockout mice, LCAT activity was impaired and oxidative stress was increased in large HDL [Lee, 2007; Van Eck 2007]. Remnant-like particle cholesterol (RLP-C) levels reflect cholesterol levels (10-15 mg/dl) of large apoE-rich HDL (probably apoE only particles) in homozygous CETP deficiency [Inazu et al. 2008]. The apoE-rich HDL contains apoA-IV as well as apoA-I [Bisgaier et al. 1991], but the RLP fraction of homozygous CETP deficiency had large amount of apoE with a trace of apoA-I and apoA-IV.

6. Molecular genetics and the ethnic difference in the frequency of human CETP deficiency 
Plasma CETP deficiency was originally reported in Japanese siblings with hyperalphalipoproteinemia (HALP) [Koizumi et al. 1985]. The first mutation was found in a splice donor site mutation in intron 14 (intron 14 G[+1]-to-A.), resulting in non-tranlsation of exon 14 and production of a stop codon in the $4^{\text {th }}$ codon encoded by exon 15. These changes resulted in decreased mRNA levels to one-third of controls and a truncated protein that appeared to be rapidly degraded [Brown et al. 1989;

\section{Gotoda et al. 1997].}

So far 20 different mutations have been found both in Asian and Caucasian populations, but predominantly in Asians [Nagano et al. 2004; Thompson et al. 2009]. Two mutations were found in both ethnic groups (R268X and intron 14 G(+1)-to-A), suggesting multiple origins of these mutations (de novo mutations) [Ai et al. 2009]. Both mutations indeed have CpG sequences as mutational hot spots for deamination of the cytosine. Although many mutations are nonsense or splicing mutations, 4 missense mutations are reported to be associated with decreased CETP activity (L151P, L261R, R282C, and D442G). Only one promoter mutation was reported at -69G>A.

Large differences in the frequency of CETP deficiency in various populations appear 
to be related to the frequency of two variants. The intron $14 \mathrm{G}(+1)$-to-A mutation is the Japanese-type mutation with the higher gene frequency $(0.8 \%$ in the general population of Japan). Homozygotes of this mutation were reported in $>50$ cases reflecting relatively higher frequency of consanguinity in Japan in the past generations.

\section{Clinical chemistry of LDL-cholesterol and HDL-cholesterol in CETP deficiency}

Homozygotic mutations result in complete CETP deficiency with a phenotype of very high HDL-C levels and relatively low LDL-C levels (mean levels of $164 \mathrm{mg} / \mathrm{dl}$ and 77 mg/dl, respectively) [Inazu et al. 1990]. Heterozygotes have a moderate increase in HDL-C (mean $66 \mathrm{mg} / \mathrm{dl}$ ) and a decrease in plasma CETP levels (mean $1.4 \mathrm{mg} / \mathrm{L}$ ) as compared to unaffected controls (53 mg/dl and $2.3 \mathrm{mg} / \mathrm{L}$ ). Asp 442 Gly (D442G) is another highly prevalent mutation in Japan (3.4\% in the general population of Japan) as well as in other Asian populations (1.7-5.9\%), although it is only partially defective in

CETP activity [Inazu et al. 1994]. The compound heterozygotes of intron 14 G(+1)-to-A and D442G produce a less severe phenotype of CETP deficiency ( $n=9$, CETP $0.9+-0.3$ [SD] mg/L, HDL-C 130+-24 mg/dL) as compared to mean levels of 
plasma CETP were 1.8+-0.6 mg/L (SD) in Japanese men and 2.0 +-0.5 in women

[Kiyohara et al. 1998].

\subsection{LDL-C measurement}

The Friedewald formula, LDL-C = TC $-\mathrm{HDL}-\mathrm{C}-(\mathrm{TG} / 5)$, is used for estimation of

LDL-C, but accurate measurement for HDL-C is required. For the precipitation method for HDL-C, the Cholesterol Reference Method Laboratory Network (CRMLN) using a heparin, Mn2+ supernatant cholesterol of plasma d >1.006 [Centers for Disease Control and Prevention (CDC)] is better than the Designed Comparison Method (DCM) using dextran-sulfate, Mg2+ supernatant cholesterol levels, since the latter precipitates apoE-rich HDL in addition to apoB-containing lipoproteins, but the former does not.

Even if accurate measurement of HDL-C is accomplished, cholesterol levels in VLDL are relatively decreased in CETP deficiency [Koizumi et al. 1991]. Therefore, the Friedewald formula would underestimate LDL-C. However, since the density between 1.019 and 1.063 includes apoE-rich large HDL such as HDL1, the LDL-C separated by ultracentrifugation would overestimate LDL-C. Suitability for the LDL-C assays has not been reported in homozygous CETP deficiency. 


\subsection{ApoE-rich HDL-C determination}

As a more suitable precipitation method for HDL-C in CETP deficiency, Chiba et al reported that $13 \%$ polyethylene glycol allows recovery of total HDL in the supernatant

[Chiba et al. 1997]. In that study, patients with complete CETP deficiency had a mean HDL-C level of $121 \mathrm{mg} / \mathrm{dl}$ detected by a commercial polyanionic reagent (dextran sulfate, sodium phosphotungstate, Mg2+), but $176 \mathrm{mg} / \mathrm{dl}$ of total HDL-C using supernatants produced by the PEG method. The difference ( $55 \mathrm{mg} / \mathrm{dl})$ may indicate cholesterol levels in apoE-rich HDL.

\section{Epidemiology of increased HDL cholesterol levels and CETP deficiency}

HDL-cholesterol could be excreted from bile as consequence of reverse cholesterol transport (RCT) involving HDL maturation from pre $\beta$ HDL to apoE-rich HDL. However, CETP would bypass the cholesterol flow from HDL to VLDL-LDL without involving the liver. Thus, CETP-mediated CE transfer would increase indirect cholesterol transport to the liver via VLDL-IDL-LDL through LDL receptor or remnant receptors pathways. In addition, HDL-cholesterol is directly transported to the liver by selective uptake of HDL-CE or FC via hepatic lipase and/ or SR-BI pathway. 
Thus, the role of the CETP pathway appears to be anti-atherogenic when LDL levels are low and TRL clearance is rapid on a low-fat diet. However, the Western-type saturated-fat diet would suppress LDL receptor expression, and the flow of HDL-derived cholesterol back to the liver would be diminished via LDL pathway. Indeed, subjects with high CETP activity may manifest lower coronary risk in the presence of low plasma TG levels [Borggreve et al. 2007]. The role of CETP in LDL-receptor deficiency (familial hypercholesterolemia) is controversial, since double heterozygotes with FH and CETP deficiency are not protected from CHD [Haraki et al. 1997]. It remains to be discussed whether slightly increased HDL-C (60 mg/dl vs. 46 $\mathrm{mg} / \mathrm{dl}$ ) is not sufficient to prevent CHD or whether lower CETP is disadvantageous in FH.

8.1 Epidemiology of HDL cholesterol

In earlier studies by Gofman et al [Gofman et al. 1966], levels of HDL2 and HDL3 were significantly decreased in patients with CHD, but HDL1 levels were not changed. In heparin-Sepharose chromatography, HDL-apoE levels were significantly decreased in survivors with myocardial infarction [Wilson et al. 1993]. In a proteomic study of 
HDL proteins, apoE levels in the HDL3 fraction were increased in patients with CHD

[Vaiser et al. 2007], but unfortunately no data were available on HDL2 or VLDL.

Inconsistency of anti-atherogenicity of HDL might be explained by how much large HDL or apoE-rich HDL are increased, as these particles are believed to have less anti-atherogenic effects compared to small HDL. When apoA-I and apoB are kept constant, HDL-C and HDL particle size may confer risk at very high values [van der

Steeg et al. 2008]. On the contrary, apoA-I is a negative risk factor even when corrected for HDL-C and apoB, suggesting that HDL number assessed by apoA-I concentration is statistically more important than HDL size for anti-atherogenicity effects. The debate over whether HDL size or its components are more important for atherogenesis should be answered by measuring specific HDL-related lipid component levels such as sphingomyelin, sphingosine-1-phosphate, and dolichol in HDL of various dyslipidemia [Kontush et al. 2007].

8.2 The role of confounding factors in increased HDL state (Table 2)

In many reports, a high HDL-C state is a negative risk factor of CHD and stroke [Kurth et al. 2007]. Since low HDL-C is inversely associated with increased TG levels, low 
HDL appeared to be a marker for disturbed TG metabolism [Schaefer et al. 1994].

However, some reports suggest a U-shape relationship with HDL-C and vascular events

[Chien et al. 2002]. Such a relationship may be associated with some confounding factors associated with increased HDL-C levels: alcohol, estrogen and exercise [Williams 1996]. There are reports of adverse interaction between alcohol and hypertension on stroke [Leppala et al. 1999]. Others have suggested an interaction between increased levels of TG and HDL-C on CHD [Jeppesen et al. 1998]. A large genetic epidemiological survey is warranted to find associations between CETP or hepatic lipase polymorphisms and CHD events, especially by interacting with environmental factors such as alcohol consumption and hormone replacement therapy. Since lower activities of hepatic lipase and SR-BI and higher CETP are characteristics of premenopausal women, consideration of gender difference is necessary in unraveling the interactions between HDL and CHD [Jansen et al. 2002].

8.3 The role of CETP mutations and polymorphisms on CHD risk A meta-analysis of studies including CETP gene SNPs of TaqIB2, -629C>A and Ile 405 Val (I405V) showed that the genotypes with low CETP may have anti-atherogenic 
effects [Thompson et al. 2008]. Our data suggested that $-1337 \mathrm{C}>\mathrm{T}$ is responsible for the anti-atherogenicity of the well-investigated TaqIB2 allele in the Japanese population [Lu et al. 2003; Takata et al. 2006]. Thus, anti-atherogenicity of lower CETP levels was also suggested in heterozygous CETP deficiency [Curb et al. 2004]. CHD prevalence appears to be low in homozygous CETP deficiency, which is compatible with findings of the Kochi Study of cross-sectional survey of disease prevalence stratified by increased HDL-cholesterol levels $>80 \mathrm{mg} / \mathrm{dl}$ and $>100 \mathrm{mg} / \mathrm{dl}$ [Moriyama et al. 1998]. Three hundred subjects with HDL-C > 100mg/dl were found in that paper, but no case with CHD was found. Indeed, high HDL-cholesterol and intron $14 \mathrm{G}(+1)>$ A variant may increase the odds for healthy aging in the Honolulu Heart Program Study [Koropatnick et al. 2008]. Consistently, recent case reports of Caucasian CETP deficiency have shown the rarity of atherosclerotic disease even though Western diets were consumed [Teh et al. 1998; Rhyne et al. 2006]. However, some investigators believe pro-atherogenicity in some cases with homozygous CETP deficiency [Nagano et al. 2005]. In contrast, there is no define CHD, but 2 cases with cerebrovascular disease were found in our cohort of homozygous CETP deficiency 
$(n=53)$

8.4 Malignancy association

In earlier studies, Keys suggested a possible association between increased HDL-C

levels and malignancy incidence [Keys 1983]. The failure of torcetrapib is a reminder of such a possible association. This issue should be assessed in studies using other CETP inhibitors.

\section{Development of CETP inhibitor}

Three compounds are currently in clinical trials, torcetrapib (CP-529414), anacetrapib (MK-859) and dalcetrapib (JTT-705/ Roche R1658). Phase III of torcetrapib was terminated on December, 2006 due to unexpected excess of mortality in the torcetrapib arm. The early termination was partially explained by hypertension due to aldosterone excess. However, the role of CETP inhibition on the increased mortality was not clearly shown, but it may be rather associated with infection or malignancy than CHD [Barter et al. 2007].

The vascular endpoints of carotid atherosclerosis and coronary atheroma volume assessed by intravascular ultrasound showed no benefit from torcetrapib over a 
background of atorvastatin treatment, despite increased levels of HDL and further decreased levels of LDL and TG [Nissen et al. 2007; Kastelein et al. 2007].

HDL-cholesterol might be excreted from bile as consequence of reverse cholesterol transport (RCT) involving HDL maturation from pre $\beta$ HDL to apoE-rich HDL. Using a CETP inhibitor, CE uptake of liver was not decreased in rabbits, but fecal sterol excretion was not increased in patients taking torcetrapib, indicating that overall RCT was not significantly induced [Brousseau et al. 2005; Kee et al. 2006; Catalano et al. 2009]. Torcetrapib did increase overall RCT assessed by cholesterol and bile acids in feces of hamsters [Tchoua et al. 2008]. Such a difference in the response to CETP inhibitor definitely needs to be clarified.

\subsection{Effects on small HDL subclasses}

Hyperalphalipoproteinemia (HALP ) caused by prednisone plus cyclosporine was ineffective in producing HDL acceptors for cholesterol efflux. The ABCA1-dependent efflux was maintained, but the non-ABCA1-dependent route appeared to be impaired

[Sviridov et al, 2006].

CETP inhibition may disturb apoA-I liberation from HDL in atherosclerotic lesions. 
Therefore, ABCA1-mediated cholesterol efflux activity to small HDL or liberated apoA-I could be compromised. However, recent studies suggest that the ABCG1 transporter may favorably induce cholesterol efflux from cells to large HDL [Yvan-Charvet et al, 2007]. Torcetrapib would increase this large HDL level, which is an active cholesterol acceptor for ABCG1 or SR-BI-mediated efflux, although the role of SR-BI-mediated cholesterol efflux remains controversial [Yvan-Charvet et al, 2008]. Although small HDL, such as HDL3 subclass, is known to protect LDL from oxidation [Davidson et al. 2009], HDL3 levels were not increased in genetic CETP deficiency, but they were moderately increased in patients with CETP inhibitors.

9.2 Effects on apoB-containing lipoproteins

By inhibiting neutral lipid transfer among lipoproteins, CE transfer from HDL to VLDL in exchange with TG was diminished. Therefore, relatively CE-poor, TG-rich VLDLs were lipolysed to LDL and VLDL-IDL-LDL were rapidly removed from the circulation probably due to LDL-receptor upregulation [Millar et al. 2006]. In LDL subclasses, small-and-dense LDL levels were decreased but large LDL levels were increased in patients with torcetrapib [Brousseau et al, 2004], which is compatible with 
a phenotype in low CETP subjects with a TaqIB2 polymorphism [Ordovas et al. 2000]. Plasma Lp(a) levels were decreased in CETP deficiency, and $~ 50 \%$ reduction of plasma Lp(a) levels was achieved by anacetrapib [Bloomfield et al. 2008]. Large HDL contains multiple apoE molecules, but such lipoproteins could be efficiently removed from the circulation via increased LDL receptor expression. Thus, increased levels of apoE-rich HDL produced by a CETP inhibitor could be offset by combination therapy with a statin, which induces LDL receptor expression and increases hepatic uptake of apoE-rich HDL. Increased RCT was found when both CETP and LDL receptor are up-regulated in the liver. Thus, combination therapy with a CETP inhibitor and a statin would result in opposite responses in the RCT pathway, a finding that would be compatible with a proposed adverse pharmacogenetic interaction between a statin and a CETP inhibitor [Regieli et al. 2008].

\section{Role of CETP in aging and longevity (Figure 2)}

CETP enhances HDL remodeling from large HDL to small subclasses including pre-HDL. However, CETP deficiency would decrease cholesterol esterification rate, thereby inhibiting maturation of pre $\beta$ HDL to $\alpha$-migrating spherical HDL. Therefore, 
in CETP deficiency, large-to small HDL remodeling is decreased and pre $\beta$ HDL

catabolism is also decreased. The levels of pre $\beta$ HDL were increased in homozygous

CETP deficiency, but those were decreased in the heterozygotes [Asztalos et al, 2004], indicating that maturation of the small HDL subclass is preserved in heterozygotes, but not in homozygotes. The difference is dependent on the magnitude of low CER and low ABCA1-mediated efflux activity.

Recent studies suggested PAF-AH (lipoprotein-associated phospholipase A2) inhibitors could inhibit sdLDL formation, thereby preventing atherosclerosis in animal model and human. Plasma paraoxonase activity was decreased in HALP with hepatic lipase deficiency [Kontush et al. 2004]. Thus, the anti-oxidant activity of HDL needs to be evaluated in patients treated with CETP inhibitors.

10.1 Effects on aging and Alzheimer's disease

A promising effect on longevity has been reported in Ashkenazi Jews, as increased homozygosity of I405V was found in offspring of individuals with exceptional longevity (mean age 98 yrs). These subjects had high HDL, low LDL and large LDL size, and low prevalence of hypertension and metabolic syndrome [Barzilai et al. 
2003].

A different CETP polymorphism (D442G) may have a protective effect against the development of Alzheimer's disease (AD), especially in apoE4 carriers in the Chinese population [Chen et al. 2007]. But, the opposite relationship between another CETP polymorphism (I405V) and AD was found in the Dutch population [Arias-Vasquez et al. 2007]. Indeed, the CETP gene haplotype was associated with both markers of cholesterol synthesis and degradation in the cerebrospinal fluid and CETP may have neuronal repair effects through PL transfer activity. Data regarding possible AD associations between genes for CETP and apoE are conflicting, and need to be resolved..

10.2 Susceptibility to infectious disease As CETP belongs to the lipopolysaccharide binding protein (LBP) gene family, a role for CETP has been suggested in infection. Since LBP and lipoprotein may be associated with the detoxification of endotoxin, apoB-containing lipoprotein levels may reflect the efficacy of LBP function [Vreugdenhil et al. 2001]. Along with an increase of LBP, plasma cholesterol, PL, LDL-C, HDL-C decrease, whereas plasma TG, VLDL and 
apoE-rich HDL tend to be increased after intravenous endotoxin [Hudgins et al. 2003;

Li et al. 2008].

In experimental endotoxemia, increased CRP levels are found with reciprocal decreases of LCAT and CETP activities [Levels et al. 2007]. CETP expression was suppressed by cytokines of TNF $\alpha$ and IL-1. PLTP deficiency led to a significant increase in LPS-induced mortality in mice [Gautier et al. 2008]. Thus, we need to consider possible disadvantages of CETP deficiency in terms of endotoxemia, because CETP would enhance the LPS binding to HDL /LDL. The liver uptake of LPS was greater in CETP-transgenic mice than controls, suggesting accelerated clearance of LPS from circulation [Cazita et al. 2008].

On the other hand, large HDL found in CETP deficiency might be protective against Schistosoma japonicum [Okamura-Noji et al. 2001].

11. Role of CETP in dyslipidemia associated with diabetes and metabolic syndrome (Table 2)

In hyperlipidemic patients, increased production of VLDL and/or decreased catabolism of LDL are major risk factors in addition to low HDL-C. Since decreased 
production rate of VLDL appears to be associated with decreased CETP activity in patients with metabolic syndrome treated by fenofibrate [Watts et al. 2006]. A CETP inhibitor may be especially useful for combined hyperlipidemia of high VLDL and low HDL levels. LDL catabolic rate is increased in CETP inhibitor, but effects on VLDL production rate have been less established.

Plasma CETP levels are increased in metabolic syndrome [Sandhofer et al. 2006]. Plasma PLTP levels are increased, but the increase in CETP is somewhat controversial in diabetes [Dallinga-Thie et al. 2007]. Plasma CETP activity was positively related with CETP mass, and negatively to HbA1c [Dullaart et al. 2004]. In diabetes, decreased sterol regulatory element binding protein (SREBP) expression may lead to lower CETP expression in the liver [MacLean et al. 2005]. Phosphoinositide 3-kinase activity is decreased in diabetes, and liver SR-BI expression is decreased [Shetty et al. 2006]. Since increased CETP activity may be beneficial in diabetes as shown in a db/db mouse study [MacLean et al. 2003], such a complex relationship should be examined in human diabetes.

In the Copenhagen City Heart Study, elevated HDL-C caused by a I405V 
polymorphism is a risk for CHD in women without hormone replacement therapy but not in men [Agerholm-Larsen et al. 2000]. Atherogenicity of CETP may be related to SR-BI expression in terms of RCT to bile cholesterol excretion. Hepatic SR-BI is induced by a diet rich in polyunsaturated fat, but suppressed by cholesterol, vitamin E and estradiol. As shown in knock-out mice, SR-BI deficiency is associated with increased HDL levels but it is pro-atherogenic [Trigatti et al. 1999].

Thus, specific attention may be required for diabetic and female patients when a CETP inhibitor is considered, because reduced SR-BI expression is assumed in those conditions. Also, usefulness of combination therapy with a statin (HMG-CoA reductase inhibitor) and a CETP inhibitor needs to be validated experimentally.

\section{Perspectives}

More studies are needed for development of HDL intervention through inhibiting plasma CETP activity. Especially, it is important to assess how to suppress plasma CETP activity. Antisense CETP therapy is of greater interest than chemical compounds because the antisense therapy would decrease plasma CETP mass.

In protection of neuronal disease, more study of cerebrospinal fluid lipoprotein is 
needed in terms of compositions of apoE and lipid transfer proteins and pharmaceutical changes in those lipoproteins. In addition to CE/TG transfer, CETP may transfer estrogen-ester and retinyl-ester but not vitamin E. Anti-oxidative local effects of CETP may be more important under oxidative stress or combined metabolic conditions of PTLP deficiency, which is defective in vitamin E transport. Thus, the role of CETP in terms of lipoprotein oxidation needs to be clarified in various setting of concurrent hyperlipoproteinemia or hormonal exposure such as estrogen. LPS is associated not only with endotoxemia, but also with vascular oxidative stress and inflammation. Therefore, role of CETP in LPS metabolism needs to be clarified in CETP deficiency and patients treated with CETP inhibitors.

\section{References}

Agellon LB, Quinet EM, Gillette TG, Drayna DT, Brown ML, Tall AR.

Organization of the human cholesteryl ester transfer protein gene.

Biochemistry, 29:1372-1376, 1990

Agerholm-Larsen B, Nordestgaard BG, Steffensen R, Jensen G, Tybjaerg-Hansen A.

Elevated HDL cholesterol is a risk fator for ischemic heart disease in white women when caused by a common mutation in the cholesteryl ester transfer protein gene. Circulation, 101:1907-1912, 2000

Ai M, Tanaka A, Shimokado K, Ohtani R, Inazu A, Kobayashi J, Mabuchi H, Nakano T, Nakajima K. A deficiency of cholesteryl ester transfer protein whose serum remnant-like particle (RLP)-triglyceride significantly increased, but 
RLP-cholesterol did not after an oral fat load.Ann Clin Biochem 2009, in press

Arias-Vasquez A, Isaacs A, Aulchenko YS, Hofman A, Oostra BA, Breteler M, van Duijn CM.

The cholesteryl ester transfer protein (CETP) gene and the risk of Alzheimer's disease.

Neurogenetics, 8:189-193, 2007

Asztalos B, Horvath KV, Kajinami K, Nartsupha C, Cox CE, Batista M, Schaefer EJ, Inazu A, and Mabuchi $H$.

Apolipoprotein composition of HDL in cholesteryl ester transfer protein deficiency.

\section{J Lipid Res, 45:448-455, 2004}

Bailhache E, Briand F, Nguyen P, Krempf M, Magot T, Ouguerram K.

Metabolism of cholesterol ester of apolipoprotein B100-containing lipoproteins in dogs: evidence for disregarding cholesterol ester transfer.

\section{Eur J Clin Invest, 34:527-534, 2004}

Barter PJ, Caulfield M, Eriksson M, et al for the ILLUMINATE Investigators. Effects of torcetrapib in patients at high risk for coronary events.

N Engl J Med, 357:2109-2122, 2007

Barter PJ, Lally JI.

The activity of an esterified cholesterol transferring factor in human and rat serum.

\section{Biochim Biophys Acta, 531:233-236, 1978}

Barzilai N, Atzmon G, Schechter C, Schaefer EJ, Cupples AL, Lipton R, Cheng S, Shuldiner AR.

Unique lipoprotein phenotype and genotype associated with exceptional longevity. 
JAMA, 290:2030-2040, 2003

Bisgaier CL, Siebenkas MV, Brown ML, Inazu A, Koizumi J, Mabuchi H, Tall AR. Familial cholesteryl ester transfer protein deficiency is associated with triglyceride-rich low density lipoproteins containing cholesteryl esters of probable intracellular origin.

\section{J Lipid Res, 32:21-33, 1991}

Bloomfield D, Carlson GL, Sapre A, Tribble D, McKenney JM, Littlejohn TW, Sisk CM, Mitchel Y, Pasternak RC.

Efficacy and safety of the cholesteryl ester transfer protein inhibitor anacetrapib as monotherapy and coadministered with atorvastatin in dyslipidemic patients.

\section{Am Heart J, 157:352-360, 2009}

Borggreve SE, Hillege HL, Dallinga-Thie GM, de Jong PE, Wolffenbuttel BHR, Grobbee DE, van Tol A, Dullaart RPF on behalf of the PREVEND Study Group. High plasma cholesteryl ester transfer protein levels may favour reduced incidence of cardiovascular events in men with low triglycerides.

Eur Heart J, 28(8):1012-1018, 2007

Brousseau ME, Schaefer EJ, Wolfe ML, Bloedon LT, Digenio AG, Clark RW, Mancuso JP, Rader DJ.

Effects of an inhibitor of cholesteryl ester transfer protein on HDL cholesterol. N Engl J Med, 350:1505-1515, 2004

Brousseau ME, Diffenderfer MR, Millar JS, et al.

Effects of cholesteryl ester transfer protein inhibition on high-density lipoprotein subspecies, apolipoprotein A-I metabolism, and fecal sterol excretion.

\section{Arterioscler Thromb Vasc Biol, 25:1-8, 2005}

Brown ML, Inazu A, Hesler CB, Agellon LB, Mann C, Whitlock ME, Marcel YL, Milne RW, Koizumi J, Mabuchi H, Takeda R and Tall AR.

Molecular basis of lipid transfer protein deficiency in a family with increased 
high-density lipoproteins.

Nature, 342(6248):448-451, 1989

Catalano G, Julia Z, Frisdal E, Vedie B, Fournier N, Le Goff W, Chapman MJ, Guerin M.

Torcetrapib differentially modulates the biological activities of HDL2 and HDL3 particles in the reverse cholesterol transport pathway.

\section{Arterioscler Thromb Vasc Biol, 29:268-275, 2009}

Cazita PM, Berti JA, Aoki C, Gidlund M, Harada LM, Nunes VS, Quintao ECR, Oliveira HCF.

Cholesteryl ester transfer protein expression attenuates atherosclerosis in ovariectomized mice.

\section{J Lipid Res, 44:33-40, 2003}

Cazita PM, Barbeiro DF, Moretti AIS, Quitao ECR, Soriano FG.

Human cholesteryl ester transfer protein expression enhances the mouse survival rate in an experimental systemic inflammation model: a novel role for Cetp.

Shock, 30:590-595, 2008

Cheema SK, Agarwal-Mawal A, Murray CM, Tucher S.

Lack of stimulation of cholesteryl ester transfer protein by cholesterol in the presence of a high-fat diet.

\section{J Lipid Res, 46:2356-2366, 2005}

Chen DW, Yang JF, Tang Z, Dong ZM, Feng ZL, Yu S, Chan P.

Cholesteryl ester transfer protein polymorphism D442G associated with a potential decreased risk for Alzheimer's disease as a modifier for APOE $\varepsilon 4$ in Chinese.

\section{Brain Research, 1187:52-57, 2008}

Cheung MC, Wolfbauer G, Albers JJ. 
Plasma phospholipids mass transfer rate: relationship to plasma phospholipid and cholesteryl ester transfer activities and lipid parameters.

Biochim Biophys Acta, 1303:103-110, 1996

Chiba $\mathrm{H}$, Akita $\mathrm{H}$, Tsuchihashi $\mathrm{K}$, et al.

Quantitative and compositional changes in high density lipoprotein subclasses in patients with various genotypes of cholesteryl ester transfer protein deficiency.

\section{J Lipid Res, 38:1204-1216, 1997}

Chien KL, Sung FC, Hsu HC, Su TC, Lin RS, Lee YT.

Apolipoprotein A-I and B and stroke events in a community-based cohort in Taiwan. Report of the Chin-Shan Community Cardiovascular Study.

Stroke 33:39-44, 2002

Curb JD, Abbott RD, Rodriguez BL, Masaki K, Chen R, Sharp DS, Tall AR.

A prospective study of HDL-C and cholesteryl ester transfer protein gene mutations and the risk of coronary heart disease in the elderly.

J Lipid Res, 45:948-953, 2004

Dallinga-Thie GM, Dullaart RPF, van Tol A.

Concerted actions of cholesteryl ester transfer protein and phospholipid transfer protein in type 2 diabetes: effects of apolipoproteins.

Curr Opin Lipidol, 18:251-257, 2007

Davidson WS, Silva RAGD, Chantepie S, Lagor WR, Chapman MJ, Kontush A. Proteomic analysis of defined HDL subpopulations reveals particle-specific protein clusters.

Arterioscler Thromb Vasc Biol, 29:870-876, 2009

Drayna D, Jarnagin AS, McLean J et al.

Cloning and sequencing of human cholesteryl ester transfer protein cDNA.

Nature, 327:632-634, 1987 
Dullaart RPF, de Vries R, Scheek L, Borggreve SE, van Gent T, Dallinga-Thie GM, Ito M, Nagano M, Sluiter WJ, Hattori H, van Tol A.

Type 2 diabetes mellitus is associated with differential effects on plasma cholesteryl ester transfer protein and phospholipid transfer protein activities and concentrations.

Scand J Clin Lab Invest, 64:205-216, 2004

Fournier N, Paul JL, Atger V, Cogny A, Soni T, de la Llera-Moya M, Rothblat G, Moatti $\mathrm{N}$.

HDL phospholipid content and composition as a major factor determining cholesterol efflux capacity from Fu5AH cells to human serum.

Arterioscler Thromb Vasc Biol, 17:2685-2691, 1997

Gautier T, Klein A, Deckert V et al.

Effect of plasma phospholipid transfer protein deficiency on lethal endotoxemia in mice.

\section{J Biol Chem, 283:18702-18710, 2008}

Gofman JW, Young W, Tandy R.

Ischemic heart disease, atherosclerosis, and longevity.

Circulation, 34:679-697,1966

Goldstein JL, Brown MS.

The LDL receptor

Arterioscler Thromb Vasc Biol, 29:431-438, 2009

Gotoda T, Kinoshita M, Ishibashi S, Inaba T, Harada K, Shimada M, Osuga J, Teramoto T, Yazaki Y, Yamada N.

Skipping of exon 14 and possible instability of both the mRNA and the resultant truncated protein underlie a common cholesteryl ester transfer protein deficicency in Japan.

Arterioscler Thromb Vasc Biol. 17:1376-1381, 1997 
Graf GA, Roswell KL, Smart EJ.

$17 \beta$-estradiol promotes the up-regulation of SR-BII in HepG2 cells and in rat livers.

\section{J Lipid Res, 42:1444-1449, 2001}

Guerin M, Bruckert E, Dolphin PJ, Turpin G, Chapman MJ.

Fenofibrate reduces plasma cholesteryl ester transfer from HDL to VLDL and normalizes the atherogenic, dense LDL profile in combined hyperlipidemia.

\section{Arterioscler Thromb Vasc Biol. 16:763-772, 1996}

Ha YC, Barter PJ.

Differences in plasma cholesteryl ester transfer activity in sixteen vertebrate species.

\section{Comp Biochem Physiol, 71B:265-269, 1982}

Haraki T, Inazu A, Yagi K, Kajinami K, Koizumi J, Mabuchi H.

Clinical characteristics of double heterozygotes with familial hypercholesterolemia and cholesteryl ester transfer protein deficiency.

Atherosclerosis, 132:229-236, 1997

Hayashi H, Campenot RB, Vance DE, Vance JE.

Apolipoprotein E-containing lipoproteins protect neurons from apoptosis via a signaling pathway involving low-density lipoprotein receptor-related protein-1.

J Neurosci, 27:1933-1941, 2007

Hernandez M, Wright SD, Cai TQ.

Critical role of cholesterol ester transfer protein in nicotinic acid-mediated HDL elevation in mice.

Biochem Biophys Res Commun, 355:1075-1080, 2007

Hudgins LC, Parker TS, Levine DM et al.

A single intravenous dose of endotoxin rapidly alters serum lipoproteins and lipid transfer proteins in normal volunteers. 


\section{J Lipid Res, 44:1489-1498, 2003}

Hussain MM, Innerarity TL, Brecht WJ, Mahley RW.

Chylomicron metabolism in normal, cholesterol-fed, and Watanabe Heritable Hyperlipidemic Rabbits.

\section{J Biol Chem, 270:8578-8587, 1995}

Ikewaki K, Rader DJ, Sakamoto T et al.

Delayed catabolism of high density lipoprotein apolipoprotein A-I and A-II in human cholesteryl ester transfer protein deficiency.

\section{J Clin Invest, 92:1650-1658, 1993}

Ikewaki K, Nishiwaki M, Sakamoto T, Ishikawa T, Fairwell T, Zech LA, Nagano M, Nakamura H, Brewer HB Jr, Rader DJ.

Increased catabolic rate of low density lipoproteins in humans with cholesteryl ester transfer protein deficiency.

\section{J Clin Invest, 96:1573-1581, 1995}

Inazu A, Brown ML, Hesler CB, Agellon LB, Koizumi J, Takata K, Maruhama Y, Mabuchi $\mathrm{H}$ and Tall AR.

Increased high-density lipoprotein levels caused by a common cholesteryl-ester transfer protein gene mutation.

N Engl J Med, 323(18):1234-1238, 1990

Inazu A, Quinet EM, Wang S, Brown ML, Stevenson S, Barr M, Moulin P and Tall AR.

Alternative splicing of the mRNA encoding the human cholesteryl ester transfer protein.

Biochemistry, 31(8):2352-2358, 1992

Inazu A, Jiang XC, Haraki T, Yagi K, Kamon N, Koizumi J, Mabuchi H, Takeda R, Takata K, Moriyama Y, Doi M and Tall A.

Genetic cholesteryl ester transfer protein deficiency caused by two prevalent 
mutations as a major determinant of increased levels of high density lipoprotein cholesterol.

\section{J Clin Invest, 94(5):1872-1882, 1994}

Inazu A, Koizumi J, Kajinami K, Kiyohara T, Chichibu K, and Mabuchi H.

Opposite effects on serum cholesteryl ester transfer protein levels between long-term treatments with pravastatin and probucol in patients with primary hypercholesterolemia and xanthoma.

\section{Atherosclerosis, 145(2): 405-413, 1999}

Inazu A, Nakajima K, Nakano T, Niimi M, Kawashiri M, Nohara A, Kobayashi J, and Mabuchi $\mathrm{H}$.

Decreased post-prandial triglyceride response and diminished remnant lipoprotein formation in cholesteryl ester transfer protein (CETP) deficiency.

\section{Atherosclerosis, 196:953-957, 2008}

Jansen $\mathrm{H}$, Verhoeven AJM, Sijbrands EJG.

Hepatic lipase: a pro- or anti-atherogenic protein?

J Lipid Res, 43:1352-1362, 2002

Jeppesen J, Hein HO, Suadicani P, Gyntelberg F.

Triglyceride concentration and ischemic heart disease. An eight-year follow-up in the Copenhagen Male Study.

Circulation, 97:1029-1036, 1998

Kastelein JJP, van Leuven SI, Burgess $\mathrm{L}$, et al for the RADIANCE 1 Investigators.

Effects of torcetrapib on carotid atherosclerosis in familial hypercholesterolemia. N Engl J Med, 356:1620-1630, 2007

Kee P, Caiazza D, Rye KA, Barrett PHR, Morehouse LA, Barter PJ.

Effects of inhibiting cholesteryl ester transfer protein on the kinetics of high-density lipoprotein cholesteryl ester transport in plasma. In vivo studies in 
rabbits.

Arterioscler Thromb Vasc Biol, 26:884-890, 2006

Keys A

Lipoprotein profile - its value in prediction

Prev Med, 12:25-31, 1983

Kiyohara T, Kiriyama R, Zamma S, Inazu A, Koizumi J, Mabuchi H and Chichibu K.

Enzyme immunoassay for cholesteryl ester transfer protein in human serum.

Clin Chim Acta, 271(2):109-118, 1998

Koizumi J,Mabuchi H, Yoshimura A, Michishita I, Takeda M, Itoh H, Sakai Y, Sakai T, Ueda K, Takeda R.

Deficiency of serum cholesteryl-ester transfer activity in patients with familial hyperalphalipoproteinaemia.

\section{Atherosclerosis, 58:175-186, 1985}

Koizumi J, Inazu A, Yagi K, Koizumi I, Uno Y, Kajinami K, Miyamoto S, Moulin P, Tall AR, Mabuchi $\mathrm{H}$ and Takeda R.

Serum lipoprotein lipid concentration and composition in homozygous and heterozygous patients with cholesteryl ester transfer protein deficiency.

Atherosclerosis, 90(2-3):189-196, 1991

Kontush A, de Faria EC, Chantepie S, Chapman MJ.

Antioxidative activity of HDL particle subspecies is impaired in hyperalphalipoproeinemia: Relevance of enzymatic and physicochemical properties.

\section{Arterioscler Thromb Vasc Biol, 24:526-533, 2004}

Kontush A, Therond P, Zerrad A, et al.

Preferential sphingosine-1-phosphate enrichment and sphingomyelin depletion are key features of small dense HDL3 particles. 
Arterioscler Thromb Vasc Biol, 27:1843-1849, 2007

Koropatnick TA, Kimbell J, Chen R, Grove JS, Donlon TA, Masaki KH, Rodriguez BL, Willcox BJ, Yano K, Curb JD.

A prospective study of high-density lipoprotein cholesterol, cholesteryl ester transfer protein gene variants, and healthy aging in very old Japanese-American men.

\section{Journal of Gerontology, 63A:1235-1240, 2008}

Krimbou L, Marcil M, Chiba H, Genest J, Jr.

Structural and functional properties of human plasma high density-sized lipoprotein containing only apoE particles

J Lipid Res, 44:884-892, 2003

Kurth T, Everett BM, Buring JE, Kase CS, Ridker PM, Gaziano JM.

Lipid levels and the risk of ischemic stroke in women.

Neurology, 68:556-562, 2007

Lee JY, Badeau RM, Mulya A, Boudyguina E, Gebre AK, Smith TL, Parks JS. Functional LCAT deficiency in human apolipoprotein A-I transgenic, SR-BI knockout mice.

\section{J Lipid Res, 48:1052-1061, 2007}

Lemarche B, Uffelman KD, Carpentier A, Cohn JS, Steiner G, Barrett PH, Lewis GF.

Triglyceride enrichment of HDL enhances in vivo metabolic clearance of HDL apoA-I in healthy men.

J Clin Invest, 103:1191-1199, 1999

Leppala JM, Paunio M, Virtamo J, Fogelholm R, Albanes D, Taylor PR, Heinonen OP.

Alcohol consumption and stroke incidence in male smokers.

Circulation, 100:1209-1214, 1999 
Levels JHM, Pajkrt D, Schultz $M$ et al.

Alterations in lipoprotein homeostasis during human experimental endotoxemia and clinical sepsis.

Biochim Biophys Acta, 1771:1429-1438, 2007

Li L, Thompson PA, Kitchens RL.

Infection induces a positive acute phase apolipoprotein $E$ response from a negative acute phase gene: role of hepatic LDL receptors.

\section{J Lipid Res, 49:1782-1793, 2008}

Lu H, Inazu A, Moriyama Y, Higashikata T, Kawashiri MA, Yu W, Huang Z, Okamura T, and Mabuchi $\mathrm{H}$.

Haplotype analyses of cholesteryl ester transfer protein gene promoter: a clue to an unsolved mystery of TaqIB polymorphism.

J Mol Med, 81(4): 246-55, 2003

Luo Y, Tall AR

Sterol upregulation of human CETP expression in vitro and in transgenic mice by an LXR element.

\section{J Clin Invest, 105:513-520, 2000}

MacLean PS, Bower JF, Vadlamudi S, Osborne JN, Bradfield JF, Burden HW, Bensch WH, Kauffman RF, Barakat HA.

Cholesteryl ester transfer protein expression prevents diet-induced atherosclerosis lesions in male $\mathrm{db} / \mathrm{db}$ mice.

Arterioscler Thromb Vasc Biol, 23:1412-1415, 2003

MacLean PS, Vadlamudi S, MacDonald KG, Pories WJ, Barakat HA.

Suppression of hepatic cholesteryl ester transfer protein expression in obese humans with the development of type 2 diabetes mellitus.

J Clin Endocrinol Metab, 90:2250-2258, 2005 
Mahley RW, Innerarity TL, Weisgraber KH, Fry DL.

Canine hyperlipoproteinemia and atherosclerosis.

Am J Pathol, 87:205-226, 1977

Masson D, Staels B, Gautier T et al.

Cholesteryl ester transfer protein modulates the effect of liver $\mathrm{X}$ receptor agonists on cholesterol transport and excretion in the mouse.

\section{J Lipid Res, 45:543-550, 2004}

Millar JS, Brousseau ME, Diffenderfer MR et al.

Effects of cholesteryl ester transfer protein inhibitor torcetrapib on apolipoprotein B100 metabolism in humans.

\section{Arterioscler Thromb Vasc Biol, 26:1350-1356, 2006}

Miyazaki O, Fukamachi I, Mori A, Hashimoto H, Kawashiri M, Nohara A, Noguchi T, Inazu A, Yamagishi M, Mabuchi H, Kobayashi J.

Formation of prebeta1-HDL during lipolysis of triglyceride-rich lipoprotein.

Biochem Biophys Res Commun, 379:55-59, 2009

Miwa K, Inazu A, Kawashiri M, et al.

Cholesterol efflux from $\mathrm{J} 774$ macrophages and Fu5AH hepatoma cells to serum is preserved in CETP-deficient patients

Clin Chim Acta, 402:19-24, 2009

Moriyama Y, Okamura T, Inazu A, Doi M, Iso H, Mouri Y, Ishikawa Y, Suzuki H, lida M, Koizumi J, Mabuchi H, Komachi Y.

A low prevalence of coronary heart disease in subjects with increased high-density lipoprotein cholesterol levels including those with plasma cholesteryl ester transfer protein deficiency.

Prev Med, 27(5Pt1):659-667, 1998

Musliner TA, Long MD, Forte TM, Krauss RM.

Size transformations of intermediate and low density lipoproteins induced by 
unesterified fatty acids.

\section{J Lipid Res, 32:903-915, 1991}

Nagano M, Yamashita S, Hirano KI, et al.

Molecular mechanisms of cholesteryl ester transfer protein deficiency in Japanese.

\section{J Atheroscler Thromb, 11:110-121, 2004}

Nagano M, Nakamura M, Kobayashi N, Kamata J, Hiramori K.

Effort angina is a middle-aged woman with abnormally high levels of serum high-density lipoprotein cholesterol.

Circ J, 69:609-612, 2005

Nissen SE, Tardif JC, Nicholls SJ, Revkin JH, Shear CL, Duggan WT, Ruzyllo W, Bachinsky WB, Lasala GP, Tuzcu EM for the ILLUSTRATE Investigators. Effects of torcetrapib on the progression of coronary atherosclerosis.

N Engl J Med, 356:1304-1316, 2007

Okamura-Noji K, Sasai K, Zhan R et al.

Cholesteryl ester transfer protein deficiency causes slow egg embryonation of Schistosoma japonicum.

Biochim Biophys Res Commun, 286:305-310, 2001

Oliveira HCF, Ma L, Milne R, Marcovina SM, Inazu A, Mabuchi H and Tall AR. Cholesteryl ester transfer protein (CETP) activity enhances plasma cholesteryl ester formation: studies in CETP transgenic mice and human genetic CETP deficiency.

Arterioscler Thromb Vasc Biol, 17(6):1045-1052, 1997

Ordovas JM, Cupples LA, Corella D, Otvos JD, Osgood D, Martinez A, Lahoz C, Coltell O, Wilson PW, and Schaefer EJ.

Association of cholesteryl ester transfer protein-TaqIB polymorphism with variations in lipoprotein subclasses and coronary heart disease risk: the 
Framingham study.

Arterioscler Thromb Vasc Biol. 20(5):1323-9, 2000

Ouguerram K, Nguyen P, Krempf M, Pouteau E, Briand F, Bailhache E, Magot T.

Selective uptake of high density lipoproteins cholesteryl ester in the dog, a species lacking in cholesteryl ester transfer protein activity. An in vivo approach using stable isotopes.

Comparative Biochem Physiol, Part B 138:339-345, 2004

Pattnaik NM, Montes A, Hughes LB, Zilversmit DB.

Cholesteryl ester exchange protein in human plasma isolation and characterization.

Biochim Biophys Acta, 530:428-438, 1978

Pruneta V, Pulcini T, Lalanne F, Marcais C, Berthezene F, Ponsin G, Moulin P.

VLDL-bound lipoprotein lipase facilitates the cholesteryl ester transfer protein-mediated transfer of cholesteryl esters from HDL to VLDL,

J Lipid Res, 40:2333-2339, 1999

Qiu X, Mistry A, Ammirati MJ et al.

Crystal structure of cholesteryl ester transfer protein reveals a long tunnel and four bound lipid molecules.

Nature structural and molecular biology, 14(2):106-113, 2007

Regieli JJ, Jukema JW, Grobbee DE, et al.

CETP genotype predicts increased mortality in statin-treated men with proven cardiovascular disease: an adverse pharmacogenetic interaction.

Eur Heart J, 29:2792-2799, 2008

Rhyne J, Ryan MJ, White C, Chimonas T, and Miller M.

The two novel CETP mutations GIn87X and GIn165X in a compound heterozygous state are associated with marked hyperalphalipoproteinemia and 
absense of significant coronary artery disease.

J Mol Med, 84(8):647-50, 2006

Robins SJ, Fasulo JM.

High density lipoproteins, but not other lipoproteins, provide a vehicle for sterol transport to bile.

J Clin Invest, 99:380-384, 1997

Sakai N, Matsuzawa Y, Hirano K, Yamashita S, Nazaki S, Ueyama Y, Kubo M, Tarui S.

Detection of two species of low density lipoprotein particles in cholesteryl ester transfer protein deficiency.

Arterioscler Thromb, 11:71-79, 1991

Sandhofer A, Kaser S, Ritsch A, Laimer M, Engl J, Paulweber B, Patsch JR, Ebenbichler CF.

Cholesteryl ester transfer protein in metabolic syndrome.

Obesity, 14:812-818, 2006

Scanu AM, Edelstein C.

HDL: bridging past and present with a look at the future.

FASEB J, 22:4044-4054, 2008

Schaefer EJ, Lamon-Fava S, Ordovas JM, Cohn SD, Schaefer MM, Castelli WP, Wilson PWF.

Factors associated with low and elevated plasma high density lipoprotein cholesterol and apolipoprotein A-I levels in the Framingham Offspring Study.

J Lipid Res, 35:871-882, 1994

Schmitz G, Assmann G.

Isolation of human serum HDL1 by zonal ultracentrifugation.

J Lipid Res, 23:903-910, 1982 
Schwartz CC, VandenBroek JM, Cooper PS.

Lipoprotein cholesteryl ester production, transfer, and output in vivo in humans J Lipid Res, 45:1594-1607, 2004

Scobey MW, Johnson FL, and Rudel LL.

Delivery of high-density lipoprotein free and esterified cholesterol to bile by the perfused monkey liver.

Am J Physiol. 257(4 Pt 1):G644-52, 1989

Shetty S, Eckhardt ERM, Post SR, van der Westhuyzen DR.

Phosphatidylinositol-3-kinase regulates scavenger receptor class B type I subcellular localization and selective lipid uptake in hepatocytes.

Arterioscler Thromb Vasc Biol, 26:2125-2131, 2006

Stevenson S, Wang S, Deng L, Tall AR.

Human plasma cholesteryl ester transfer protein consists of a mixture of two forms reflecting variable glycosylation at Asparagine341.

Biochemistry, 32:5121-5126, 1993

Sviridov D, Chin-Dusting J, Nestel P, Kingwell B, Hoang A, Olchawa B, Starr J, Dart A.

Elevated HDL cholesterol is functionally ineffective in cardiac transplant recipients: Evidence for impaired reverse cholesterol transport.

Transplantation, 81:361-366, 2006

Tanigawa H, Billheimer JT, Tohyama J, Zhang Y, Rothblat G, Rader DJ.

Expression of cholesteryl ester transfer protein in mice promotes macrophage reverse cholesterol transport.

Circulation. 116(11):1267-73, 2007

Takata M, Inazu A, Katsuda S, Miwa K, Kawashiri M, Nohara A, Higashikata T, Kobayashi J, Mabuchi $\mathrm{H}$, and Yamagishi M. 
CETP (cholesteryl ester transfer protein) promoter $-1337 \mathrm{C}>\mathrm{T}$ polymorphism protects against coronary atherosclerosis in Japanese patients with heterozygous familial hypercholesterolaemia.

Clin Sci (Lond), 111(5):325-331, 2006

Tchoua U, D'Souza W, Mukhamedova N, Blum D, Niesor E, Mizrahi J, Maugeais C, Sviridov D.

The effect of cholesteryl ester transfer protein overexpression and inhibition on reverse cholesterol transport.

Cardiovasc Res, 77:732-739, 2008

Teh EM, Dolphin PJ, Breckenridge WC, and Tan $\mathrm{MH}$.

Human plasma CETP deficiency: identification of a novel mutation in exon 9 of the CETP gene in a Caucasian subject from North America.

\section{J Lipid Res, 39:442-456, 1998}

Thompson A, Angelantonio ED, Sarwar N, Erqou S, Saleheen D, Dullaart RPF, Keavney B, Ye Z, Danesh J.

Association of cholesteryl ester transfer protein genotypes with CETP mass and activity, lipid levels, and coronary risk.

JAMA, 299:2777-2788, 2008

Thompson JF, Reynolds JM, Williams SP, Wood LS, Paciga SA, Lloyd DB.

Frequency and function of CETP variants among individuals of Asian ancestry.

Atherosclerosis, 202:241-247, 2009

Trigatti B, Rayburn $\mathrm{H}$, Vinals $M$ et al.

Influence of the high density lipoprotein receptor SR-BI on reproductive and cardiovascular pathophysiology.

Proc Natl Acad Sci USA, 96:9322-9327, 1999

Vaisar T, Pennathur S, Green PS et al. 
Shotgun proteomics implicates protease inhibition and complement activation in the anti-inflammatory properties of HDL.

\section{J Clin Invest, 117:746-756, 2007}

Van der Hoorn JWA, de Haan W, Berbee JFP, Havekes LM, Jukema JW, Rensen PCN, Princen HMG.

Niacin increases HDL by reducing hepatic expression and plasma levels of cholesteryl ester transfer protein in APOE*3Leiden.CETP Mice.

\section{Arterioscler Thromb Vasc Biol, 28:2016-2011, 2008}

Van der Steeg WA, Holme I, Boekholdt SM, et al.

High-density lipoprotein cholesterol, high-density lipoprotein particle size, and apolipoprotein A-I: Significance for cardiovascular risk.

JAMA, 51:634-642, 2008

Van Eck M, Hoekstra M, Hildebrand RB, Yaong Y, Stengel D, Kruijt JK, Sattler W, Tietge UJF, Ninio E, Van Berkel TJC, Pratico D.

Increased oxidative stress in scavenger receptor BI knockout mice with dysfunctional HDL.

Arterioscler Thromb Vasc Biol, 27:2413-2419, 2007

Vreugdenhil ACE, Patricia Snoek AM, van't Veer C, Greve JWM, Buurman WA. LPS-binding protein circulates in association with apoB-containing lipoproteins and enhances endotoxin-LDL/VLDL interaction.

J Clin Invest, 107:225-234, 2001

Wang S, Wang X, Deng L, Rassart E, Milne RW, Tall AR.

Point mutagenesis of carboxyl-terminal amino acids of cholesteryl ester transfer protein.

J Biol Chem, 268:1955-1959, 1993

Wang X, Driscoll DM, Morton RE.

Molecular cloning and expression of lipid transfer inhibitor protein reveals its 
identity with apolipoprotein $\mathrm{F}$.

J Biol Chem, 274:1814-1820, 1999

Watts GF, Ji J, Chan DC, Ooi EMM, Johnson AG, Rye KA, Barrett PHR.

Relationships between changes in plasma lipid transfer proteins and apolipoprotein B-100 kinetics during fenofibrate treatment in the metabolic syndrome.

Clin Sci, 111:193-199, 2006

Williams PT.

High-density lipoprotein cholesterol and other risk factors for coronary heart disease in female runners.

N Engl J Med, 334:1298-1303, 1996

Wilson HM, Patel JC, Russell D, Skinner ER.

Alterations in the concentration of an apolipoprotein E-containing subfraction of plasma high density lipoprotein in coronary heart disease.

Clin Chim Acta, 220:175-187, 1993

Yvan-Charvet L, Matsuura F, Wang N, Bamberger MJ, Nguyen T, Rinninger F, Jiang XC, Shear $C L$, Tall AR.

Inhibition of cholesteryl ester transfer protein by torcetrapib modestly increases macrophage cholesterol efflux to HDL.

Arterioscler Thromb Vasc Biol, 27:1132-1138, 2007

Yvan-Charvet L, Pagler TA, Wang N, Senokuchi T, Brundert M, Li H, Rinninger F, Tall AR.

SR-BI inhibits ABCG1-stimulated net cholesterol efflux from cells to plasma HDL.

J Lipid Res, 49:107-114, 2008

Zhang A, Gao S, Fan J, Huang W, Zhao T, Liu G.

Increased plasma HDL cholesterol levels and biliary cholesterol excretion in 
hamsters by LCAT overexpression.

FEBS Letters, 570:25-29, 2004 
Table 1. Plasma endogenous and exogenous LCAT activity and exogenous CETP activity in young women $(n=38)$

\begin{tabular}{|l|l|l|l|}
\hline HDL enzyme/ protein & Method & Mean (SD) & Range \\
\hline LCAT, endogenous & $\begin{array}{l}\text { Self substrate method } \\
\text { Nagasaki and Akanuma (1977) }\end{array}$ & 110 (20) & $\mathbf{8 0 - 1 8 0}$ \\
\hline LCAT, exogenous & $\begin{array}{l}\text { Common substrate method } \\
\text { Manabe et al (1987) }\end{array}$ & 590 (110) & $\mathbf{3 3 0 - 9 0 0}$ \\
\hline CETP & $\begin{array}{l}\text { NBD-cholesteryl ester transfer } \\
\text { activity between proteoliposome } \\
\text { to VLDL }\end{array}$ & 210 (30) & $150-290$ \\
\hline
\end{tabular}

All units are $\mathrm{nmol} / \mathrm{ml} / \mathrm{h}$.

Endogenous LCAT activity of cholesterol esterification rate is only $~ 20 \%$ of exogenous LCAT activity, the latter is correlated with plasma LCAT mass. Endogenous LCAT activity is only $~ 50 \%$ of plasma CETP activity, therefore HDL-FC/CE ratio could be altered in heterozygous CETP deficiency. 
Table 2. Gender difference in HDL-associated biological activities

\begin{tabular}{|l|l|l|l|}
\hline & CETP & Hepatic lipase & SR-BI \\
\hline Men & Low & High & High \\
\hline Premenopausal women & High & Low & Low \\
\hline
\end{tabular}




\section{Figure legends}

\section{Figure 1. Schema for HDL metabolism}

Plasma cholesteryl ester transfer protein (CETP) facilitates to exchange neutral lipids of CE and TG between chylomicron (CM)/ VLDL and HDL2. HDL-TG is provided by CETP, and it is subsequently hydrolyzed by hepatic lipase (HL). The synthetic rate of pre $\beta$ 1HDL is positively correlated with lipoprotein lipase (LPL)-mediated lipolysis or PLTP-mediated PL/FC transfer and increased cholesterol efflux by ABCA1 transporter. On the other hand, catabolic rate of pre $\beta 1 \mathrm{HDL}$ is correlated with cholesterol esterification rate by lecithin: cholesterol acyltransferase (LCAT). Thus, pre $\beta 1$ HDL levels are determined by activities of LPL, PLTP, ABCA1, and LCAT.

Figure 2. Differential metabolic fate of HDL in heterozygous and homozygous CETP deficiency

(A) In heterozygotes, both CM/VLDL lipolysis and cellular ABCA1-mediated FC/PL efflux are maintained. Also, LCAT reaction is relatively preserved. Thus, decrease in pre $\beta 1 \mathrm{HDL}$ indicates that HDL maturation is not disturbed.

(B) In homozygotes, both CM/VLDL lipolysis is enhanced and the cellular efflux are diminished. Also, LCAT reaction is severely suppressed. Thus, pre $\beta 1 \mathrm{HDL}$ is accumulated in plasma. 
Table 2R. Gender difference in HDL-associated biological activities

\begin{tabular}{|l|l|l|l|l|l|l|}
\hline & \multicolumn{3}{|l|}{ Transfer proteins, enzyme, receptor } & \multicolumn{2}{l|}{ Lipoprotein phenotype } \\
\hline & CETP & PLTP & $\begin{array}{l}\text { Hepatic } \\
\text { lipase }\end{array}$ & SR-BI & HDL2b & pre $\beta$-HDL \\
\hline Men & low & high & high & high & low & high \\
\hline Women $^{\star}$ & high & low & low & low & high & low \\
\hline
\end{tabular}

*premenopausal state

LPL activity is not different between men and women. 
Figure 1.

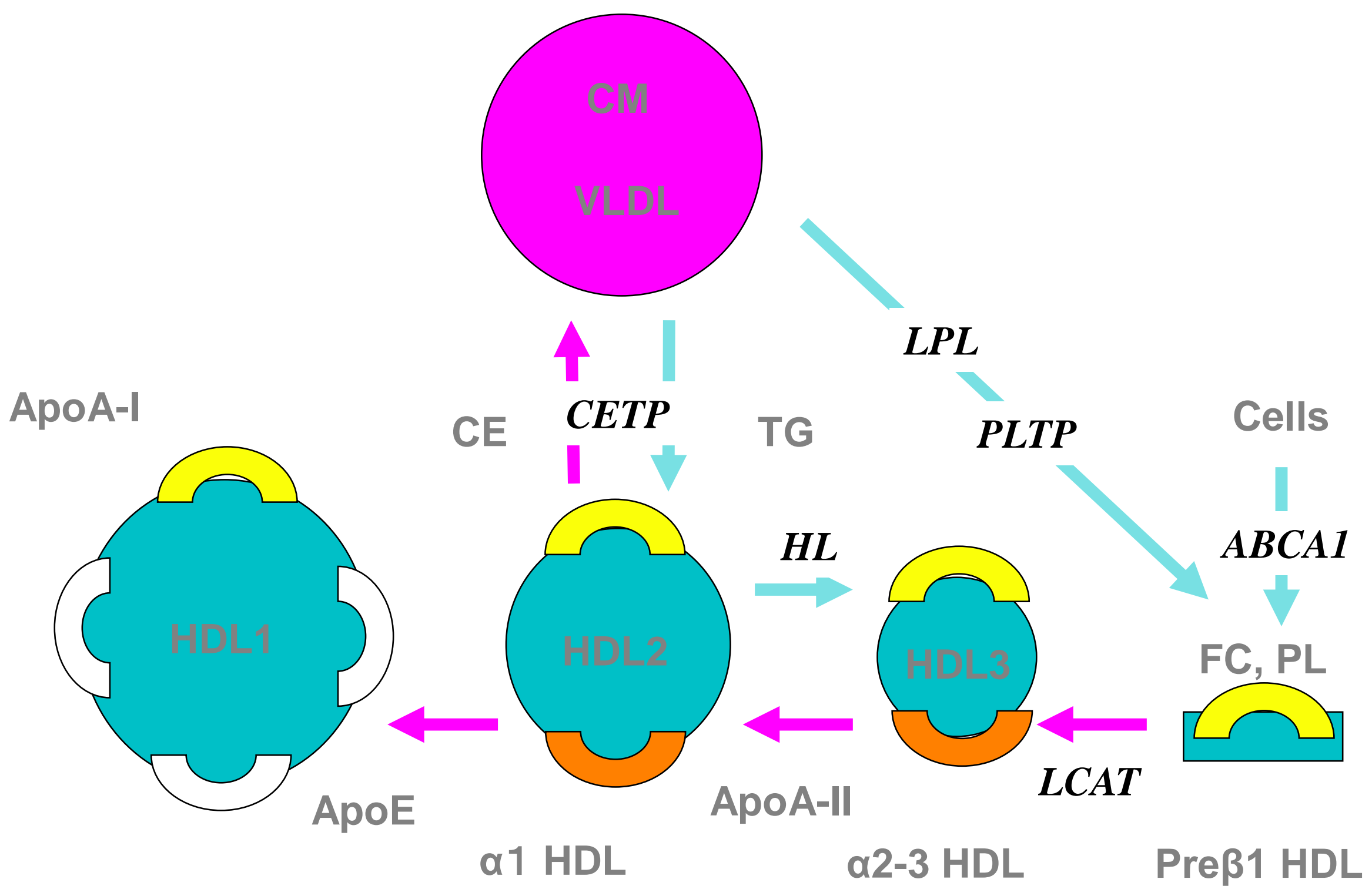


Figure $2(A)$

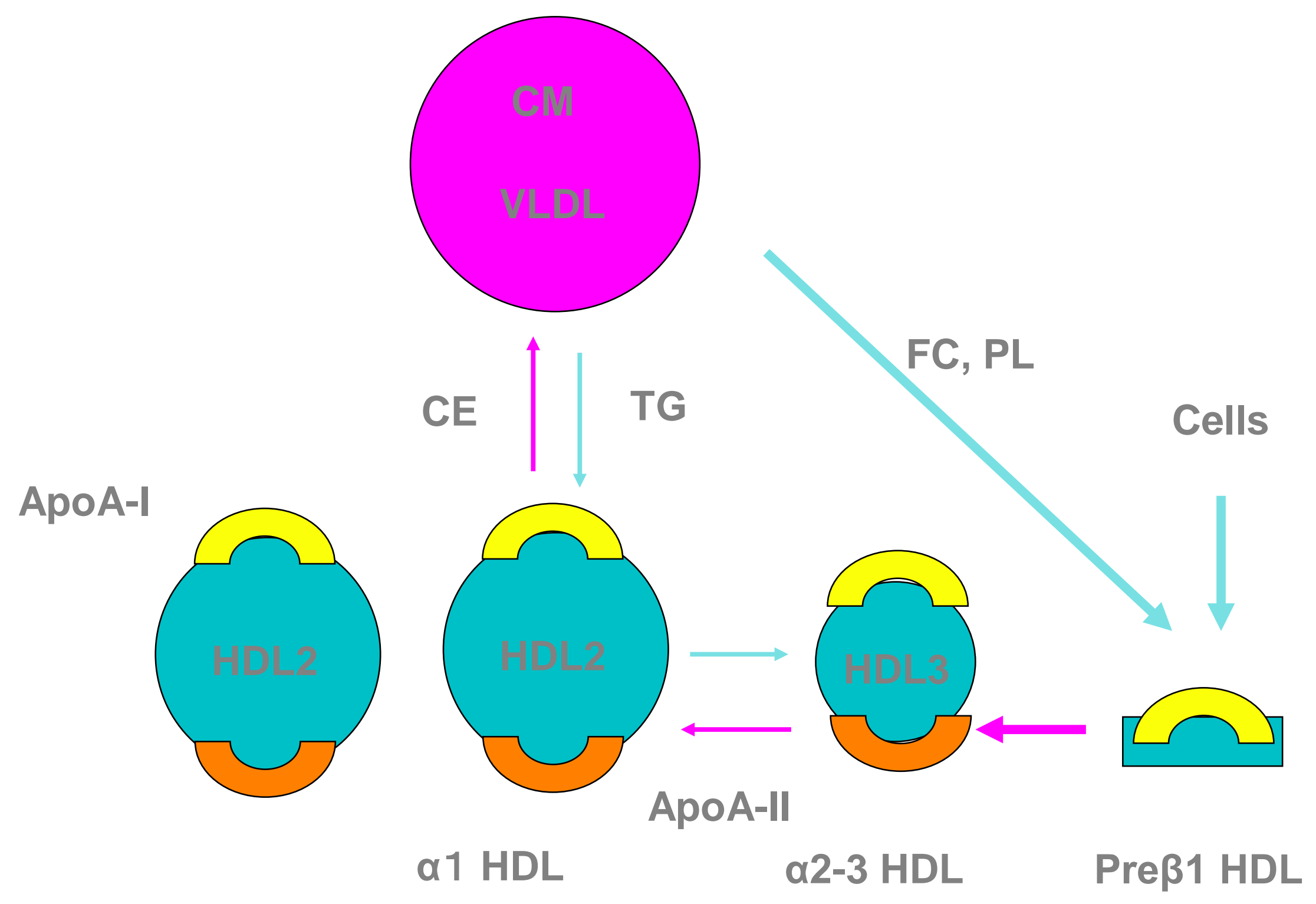


Figure 2 (B)

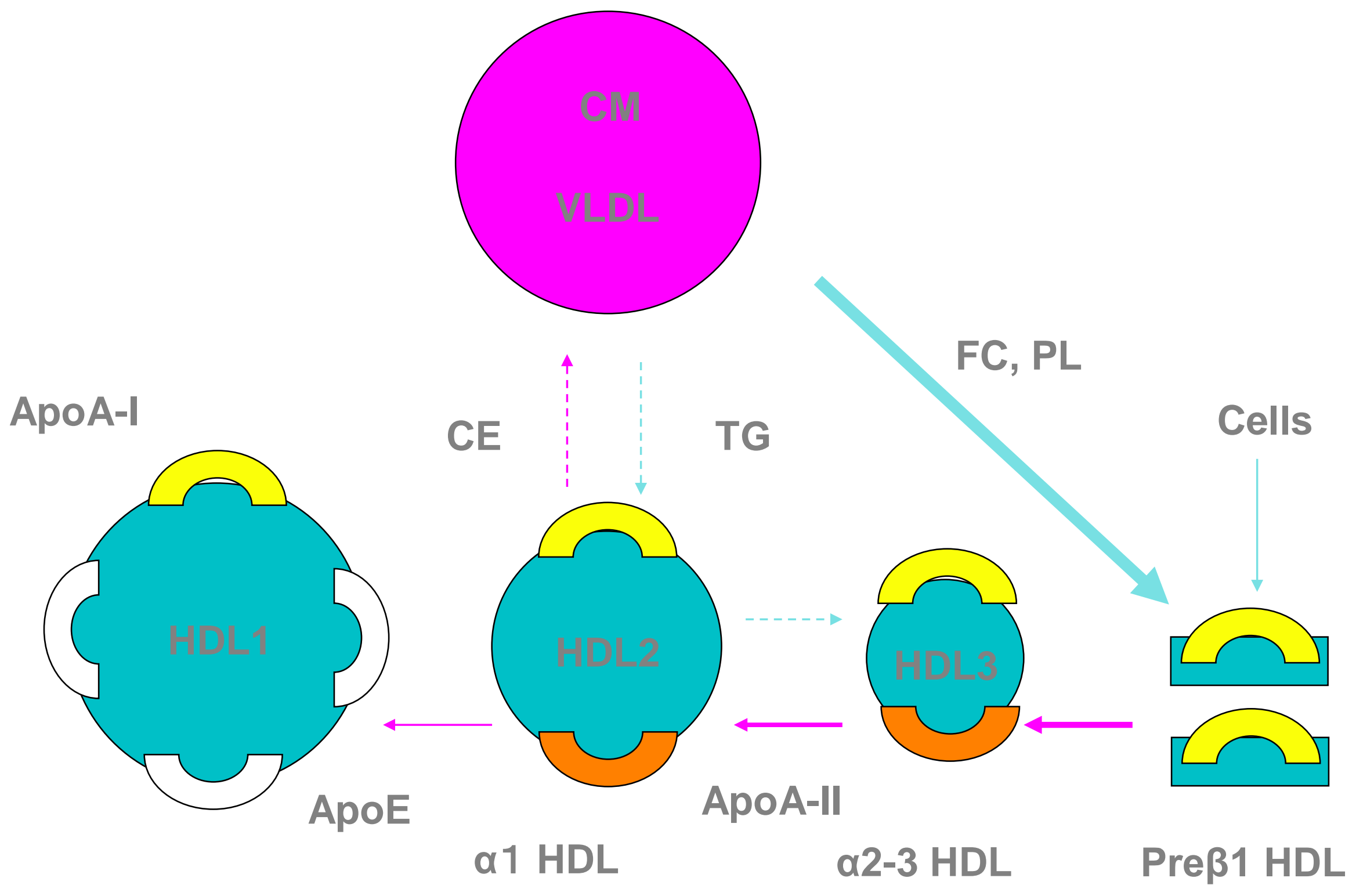


Notes added in the proof

13. Low CETP status, genetic or environmental?

Recent publications suggested that low CETP mass is associated with lipid-lowering drugs, history of myocardial infarction, diabetes, smoking, and inflammation with elevations of CRP and IL-6 (Ritsh et al, 2010). Indeed, CETP expression was decreased in leukocytes and macrophages in acute coronary syndrome (Ye et al. 2008), suggesting down-regulation of CETP expression during acute inflammation.

In addition, Vasan et al have shown that low CETP activity was associated with greater cardiovascular risk in a prospective study of the Framingham Heart Study (Vasan et al. 2009). Thus, cause of low CETP activity needs to be clarified to insight conflicting data between CETP activity and cardiovascular risk. Thus, both genetic and environmental factors need to be assessed in a cardiovascular health study including plasma CETP mass or activity.

\section{References}

Ritsch A, Scharnagl H, Eller P, Tancevski I, Duwensee K, Demetz E, Sandhofer A, Boehm BO, Winkelmann BR, Patsch JR, Marz W.

Cholesteryl ester transfer protein and mortality in patients undergoing coronary angiography. The Ludwigshafen Risk and Cardiovascular Health Study.

Circulation, 121:366-374, 2010

Vasan RS, Pencina MJ, Robins SJ, Zachariah JP, Kaur G, D'Agostino RB, Ordovas JM.

Association of circulating cholesteryl ester transfer protein activity with incidence of cardiovascular disease in the community.

Circulation, 120:2414-2420, 2009

Ye D, Kraaijeveld AO, Grauss RW, Willems SM, Van Vark-van der Zee LC, de Jager SCA, Jauhiainen M, Kuivenhoven JA, Dallinga-Thie GM, Atsma DE, 
Hogendoorn PCW, Biessen EAL, Van Berkel TJC, Jukema JW, van Eck M.

Reduced leucocyte cholesteryl ester transfer protein expression in acute coronary syndromes.

J Intern Med, 246:571-585, 2008 